\title{
BIOLOGIA REPRODUTIVA E ESTRUTURA POPULACIONAL DE NEOCALLICHIRUS MARYAE KARASAWA, 2004 EM UM BANCO ARENO-LAMOSO NO NORDESTE DO BRASIL (CRUSTACEA, AXIIDEA, CALLIANASSIDAE)
}

\author{
Botter-Carvalho, M.L. ${ }^{1,}{ }^{*}$; Costa, L.B. ${ }^{1}$; Marinho, N.C.M. ${ }^{1}$ \& Carvalho, P.V.V.C. ${ }^{1}$ \\ ${ }^{1}$ Universidade Federal Rural de Pernambuco (UFRPE), Campus Recife, Laboratório de Ecologia do Bentos Costeiro (Lebenc). \\ *Autor correspondente: monicabotter@yahoo.com.br
}

\begin{abstract}
Neocallichirus maryae é um camarão escavador habitante de fundos arenosos de ambientes costeiros, com registros da Flórida, Bahamas, Antilhas, Colômbia, Venezuela e Brasil (Ceará, Pernambuco e Alagoas). Apesar da ampla distribuição e da sua importância como engenheiro ecossistêmico, sua ecologia populacional ainda é desconhecida. O presente trabalho descreve aspectos da estrutura populacional, reprodução, crescimento relativo e fecundidade de N. maryae na praia de casa caiada, município de Olinda, Pernambuco, Brasil. A praia é protegida por quebra-mares e apresenta baixo hidrodinamismo. As coletas foram realizadas mensalmente durante a baixa-mar, entre os meses de setembro de 2011 a outubro de 2012, utilizando bomba de sucção manual. As relações morfométricas entre os comprimentos da carapaça (CC), do propódio da quela maior (CP) e total (CT) foram investigados, considerando o CL como a variável independente. O tamanho de maturação sexual foi estimado pelo método dos mínimos quadrados. Foram capturados 110 indivíduos, sendo 55 machos e 55 fêmeas. A razão sexual não foi significativamente diferente de 1:1, não havendo diferenças ao longo dos meses. As fêmeas alcançaram tamanhos máximos de carapaça superiores aos machos. Nenhum padrão de lateralidade dos quelípedes foi observado para machos e fêmeas. Durante o período de estudo apenas uma fêmea ovígera foi coletada, com 2190 embriões. As regressões entre CC e CP mostraram um padrão crescimento isométrico para fêmeas e alométrico positivo para machos. A distribuição de frequência de tamanho exibiu um padrão unimodal para ambos os sexos. A espécie analisada apresenta aspectos populacionais semelhantes a outros calianassídeos. Portanto, os resultados obtidos contribuem para aumentar o conhecimento sobre a ecologia dos camarões escavadores, visando a preservação da biodiversidade.
\end{abstract}

Palavras-chave: Decapoda, camarão escavador, fecundidade, reprodução, crescimento relativo. 